\title{
Genes and enzymes of the acetyl cycle of arginine biosynthesis in the extreme thermophilic bacterium Thermus thermophilus HB27
}

\author{
Margot Baetens, ${ }^{1,2} \dagger$ Christianne Legrain, ${ }^{3}$ Anne Boyen ${ }^{1,2}$ \\ and Nicolas Glansdorff',2,3 \\ Author for correspondence: Nicolas Glansdorff. Tel: +3225267275 . Fax: +3225267273. \\ e-mail : ceriair@ulb.ac.be
}

Microbiologie, Vrije

Universiteit Brussel1', Vlaams Interuniversitair Instituut voor Biotechnologie 2 and Research Institute CERIACOOVI ${ }^{3}$, Emile Grysonlaan 1, B-1070 Brussel, Belgium

\begin{abstract}
An arginine biosynthetic gene cluster, argC-argJ, of the extreme thermophilic bacterium Thermus thermophilus HB27 was isolated by heterologous complementation of an Escherichia coli acetylornithinase mutant. The recombinant plasmid (pTHM1) conferred ornithine acetyltransferase activity to the $E$. coli host, implying that $T$. thermophilus uses the energetically more economic pathway for the deacetylation of acetylornithine. PTHM1 was, however, unable to complement an $E$. coli argA mutant and no acetylglutamate synthase activity could be detected in $E$. coli argA cells containing PTHM1. The $T$. thermophilus argJ-encoded enzyme is thus monofunctional and is unable to use acetyl-CoA to acetylate glutamate (contrary to the Bacillus stearothermophilus homologue). Alignment of several ornithine acetyltransferase amino acid sequences showed no obvious pattern that could account for this difference; however, the monofunctional enzymes proved to have shorter $\mathrm{N}$-termini. Sequence analysis of the PTHM1 $3.2 \mathrm{~kb}$ insert revealed the presence of the arg $\mathrm{C}$ gene (encoding $\mathrm{N}$-acetylglutamate-5semialdehyde dehydrogenase) upstream of the argJ gene. Alignment of several $\mathbf{N}$-acetylglutamate-5-semialdehyde dehydrogenase amino acid sequences allowed identification of two strongly conserved putative motifs for cofactor binding: a putative FAD-binding site and a motif reminiscent of the NADPH-binding fingerprint. The relationship between the amino acid content of both enzymes and thermostability is discussed and an effect of the GC content bias is indicated. Transcription of both the argC and arg $J$ genes appeared to be vector-dependent. The argJ-encoded enzyme activity was twofold repressed by arginine in the native host and was inhibited by ornithine. Both upstream of the $\arg C$ gene and downstream of the argJ gene an ORF with unknown function was found, indicating that the organization of the arginine biosynthetic genes in $T$. thermophilus is new.
\end{abstract}

Keywords: Thermus thermophilus, argCJ sequence, ornithine acetyltransferase, $\mathrm{N}$-acetylglutamate-5-semialdehyde dehydrogenase, regulation

\section{INTRODUCTION}

Thermus thermophilus is an extreme thermophilic bacterium growing optimally at $72^{\circ} \mathrm{C}$ and up to $85^{\circ} \mathrm{C}$.
One of the first organisms of this type to have been isolated (Oshima \& Imahori, 1974), it has been used ever since as a model system for studies on thermophily. As part of a general programme focused on the

Abbreviations: OAT, ornithine acetyltransferase; NAGSD, $\mathrm{N}$-acetylglutamate-5-semialdehyde dehydrogenase.

† Present address : Department of Microbiology and Immunology, Sherman Fairchild Science Building, 299 Campus Drive, Stanford University, 94305-5124, USA.

The EMBL accession number for the sequence reported in this paper is $\mathrm{Y} 10525$. 


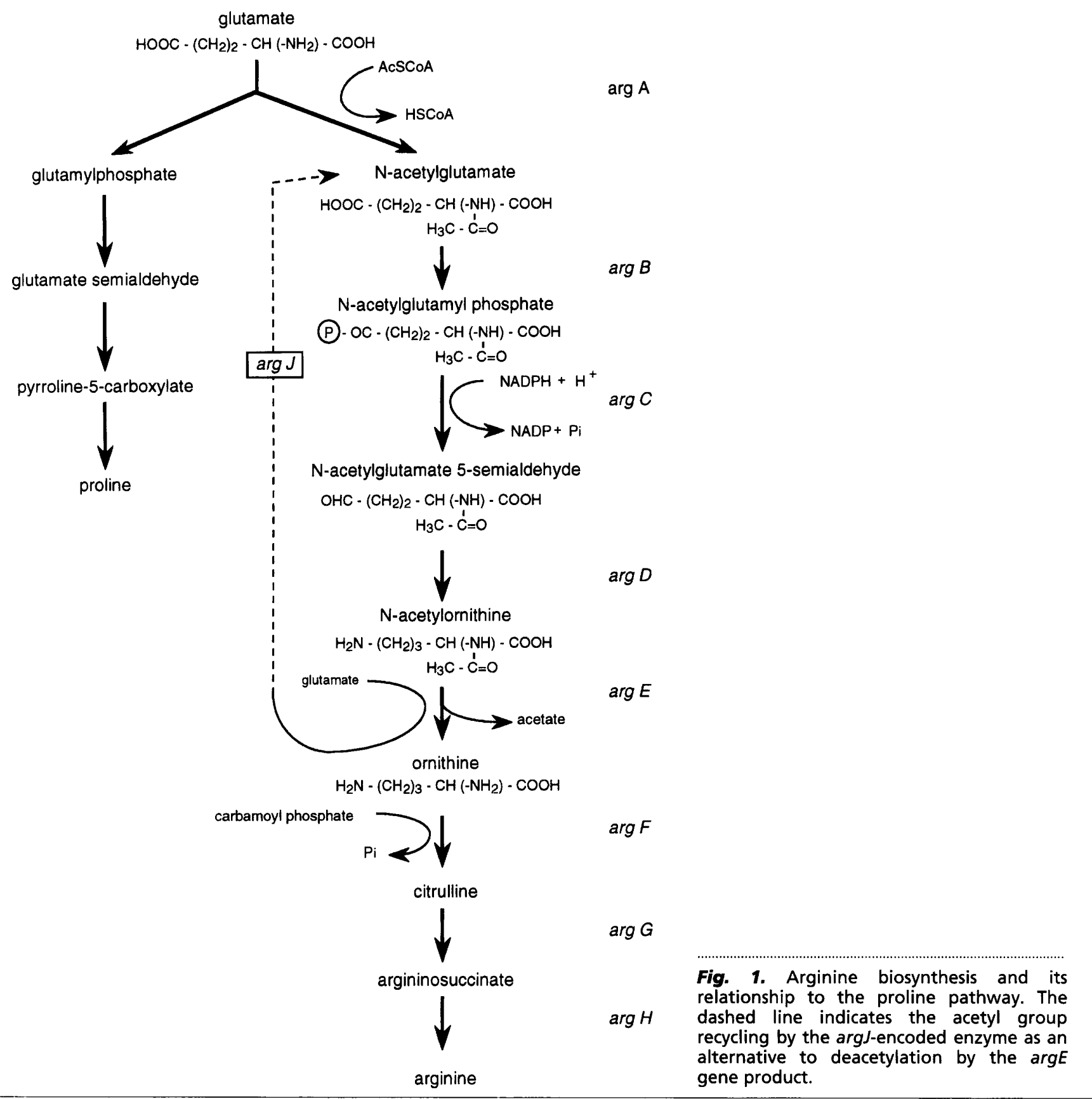

molecular physiology of thermophilic prokaryotes, we have embarked upon the enzymic and genetic characterization of the arginine and pyrimidine systems in Thermus (Van de Casteele, 1994; Van de Casteele et al., 1990, 1994, 1997a, b).

Among primary metabolic systems arginine biosynthesis is notable for its complexity and variability at the genetic level, and by its connection with several other pathways such as pyrimidine and polyamine biosynthesis, and diverse degradative pathways (see Cunin et al., 1986; Glansdorff, 1996). Moreover, the pattern of arginine synthesis is not unique (see below), a rare instance in biosynthetic metabolism.
The initial steps of the arginine biosynthetic pathway proceed via $\mathrm{N}$-acetylated intermediates (Fig. 1). Two alternative ways have evolved to split off the acetyl group from $\mathrm{N}$-acetylornithine: in the linear pathway, which is found in the Enterobacteriaceae (Cunin et al., 1986) and in Sulfolobus solfataricus (Van de Casteele et al., 1990) acetylornithinase (EC 3.5.1.16, encoded by $\arg E$ ) catalyses the hydrolysis of $\mathrm{N}$-acetylornithine into the arginine precursor ornithine and acetate. All other prokaryotes and the eukaryotic microbes investigated up to now use an energetically more economic pathway which recycles the acetyl group onto glutamate, yielding acetylglutamate. This reaction is catalysed by ornithine acetyltransferase (OAT, EC 2.3.1.35, encoded by $\mathrm{arg} J$ ). 
In these organisms the first step in the pathway fulfils an anaplerotic role: once $\mathrm{N}$-acetylornithine is synthesized the action of $\mathrm{N}$-acetylglutamate synthase (encoded by $\arg A$ ) becomes superfluous.

In Bacillus stearothermophilus (Sakanyan et al., 1993) the $\mathrm{arg} J$ gene product is bifunctional: the enzyme is able to use both acetyl-CoA and $\mathrm{N}$-acetylornithine to acetylate glutamate, thus expressing both $\mathrm{N}$-acetylglutamate synthase and OAT activities. Also, in Neisseria gonorrhoeae (Martin \& Mulks, 1992) and in Bacillus subtilis (O'Reilly \& Devine, 1994) the argJ gene was shown to complement both $\arg A$ and $\operatorname{argE}$ Escherichia coli auxotrophs. In Saccharomyces cerevisiae, the $A R G 7$ gene (the yeast $\arg J$ homologue) is able to complement both yeast ARG2 and ARG7 mutants as well as E. coli $\arg A$ and $\arg E$ mutants; the corresponding protein displays acetylglutamate synthase activity when overexpressed (Crabeel et al., 1997).

On the other hand, in Pseudomonas aeruginosa, the two enzyme activities are separable by gel filtration (Haas \& Holloway, 1977); the argJ gene product of Streptomyces coelicolor is unable to complement an E. coli $\arg A$ mutant (Hindle et al., 1994) and in Corynebacterium glutamicum the argJ gene was shown to encode a monofunctional enzyme displaying only OAT activity (Sakanyan et al., 1996).

In the micro-organisms utilizing the linear pathway, the first enzyme in the pathway $-\mathrm{N}$-acetylglutamate synthase - is the target for feedback inhibition by arginine (Vyas \& Maas, 1963). Since in the organisms which recycle the acetyl group the first enzyme fulfils an anaplerotic role, it is the second enzyme of the pathway ( $N$-acetylglutamate-5-phosphotransferase) which is usually the subject of feedback inhibition by arginine (see Cunin et al., 1986; Davis, 1986). However, in Thermus ZO5 only OAT was feedback-inhibited by the pathway's end product (Van de Casteele et al., 1990). In $B$. stearothermophilus, $\mathrm{N}$-acetylglutamate-5-phosphotransferase is not feedback-inhibited either. Instead, it is also the OAT activity which is inhibited, although not by arginine but by ornithine (Sakanyan et al., 1993). This was also observed for $C$. glutamicum OAT (Sakanyan et al., 1996) and for its Sacch. cerevisiae homologue (Crabeel et al., 1997). Sulf. solfataricus (using the linear pathway) and Thermotoga maritima (using the cyclic pathway) appear devoid of feedback inhibition (Van de Casteele et al., 1990) under the conditions applied.

The organization of the arginine biosynthetic genes differs greatly amongst the different systematic groups. In $P$. aeruginosa and $N$. gonorrboeae the arg genes are not clustered at all (Haas \& Holloway, 1977; Picard \& Dillon, 1989). In the Enterobacteriaceae, an argECBH cluster is found in E. coli (Glansdorff, 1965) (where the $\arg E$ and $\operatorname{argCBH}$ genes are transcribed divergently from converging promoters facing each other over a common control region; Elseviers et al., 1972; Pouwels et al., 1974); an argECBH cluster is also found in
Salmonella typhimurium (Sanderson, 1970) and an argECBGH cluster is present in Proteus mirabilis and Serratia marcescens (Prozesky, 1968; Matsumoto et al., 1975). The other arg genes are scattered over the chromosome. In B. subtilis two operons are found:

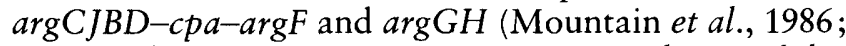
Harwood \& Baumberg, 1977); in B. stearothermophilus there is an $\operatorname{argCJBD}$ operon (Sakanyan et al., 1993; Savchenko et al., 1996), in C. glutamicum an argCJBDF cluster (Sakanyan et al., 1996) and in Strep. coelicolor an $\operatorname{argCJB}$ one (Hindle et al., 1994). In these last three organisms nothing is known about possible further downstream arginine genes. The data of Ludovice $e t$ al. (1992) suggest that in Streptomyces clavuligerus argC and $\operatorname{argJ}$ are linked. In Vibrio 2693 there exists an $\operatorname{argCBFGH}$ gene organization (Liang et al., 1996) and there are indications that upstream of this cluster a divergently expressed $\arg E$, and downstream an $\arg A$ gene are present (Liang, 1997; Z. Liang, Y. Xu \& N. Glansdorff, unpublished).

From the above it appears that further studies on arginine metabolism in $T$. thermophilus are justified from several convergent points of view. The organism is not only a thermophilic paradigm in the Bacterial domain but it also belongs to a deeply branching line of descent on the 16S RNA life tree (Woese, 1987; Williams, 1992). This suggests that, in general, comparisons of gene structure and gene organization between Thermus and other prokaryotes could be particularly interesting. In the case of arginine biosynthesis, which has also gained the status of a model system in molecular physiology, our present knowledge remains limited to the identification of the pathway (Van de Casteele et al., 1990); no genetic data are available. Regarding argJ in particular, it is not known whether this gene encodes a mono- or a bifunctional enzyme. In this paper we have characterized the gene encoding the acetylornithine deacetylating enzyme of $T$. thermophilus; it is the first gene of this kind to have been described in an extreme thermophilic bacterium. We have also examined some of the regulatory properties of the cognate enzyme and carried out its partial purification. The $\operatorname{argC}$ gene encoding $\mathrm{N}$-acetylglutamate-5semialdehyde dehydrogenase (NAGSD, EC 1.2.1.38) was found to be adjacent to $\mathrm{argJ}$.

\section{METHODS}

Bacterial strains and plasmids. T. thermophilus HB27 wildtype strain is described by Oshima \& Imahori (1974) and was obtained from Dr Y. Koyama. hsd E. coli arginine auxotrophs $\mathrm{XA} 4(\arg A), \mathrm{XC} 33(\arg C)$ and XS1D2 $(\arg E)$ are described by Mountain et al. (1984) and were kindly provided by Dr S. Baumberg. XA4argE is described by Sakanyan et al. (1992) and was constructed in this laboratory. The $E$. coli plasmid vector pUC19 (Messing \& Vieira, 1982) was purchased from Boehringer Mannheim and pBluescript II KS(+) (Short et al., 1988) from Stratagene.

Culture conditions. E. coli strains were grown at $37^{\circ} \mathrm{C}$ in $\mathrm{L}$ broth and in synthetic 132 medium (Falmagne et al., 1965). Succinate was added to $0 \cdot 25 \%(\mathrm{w} / \mathrm{v})$ where necessary. 
Concentrations of antibiotics were $25 \mu \mathrm{g}$ ampicillin $\mathrm{ml}^{-1}$ and $20 \mu \mathrm{g}$ tetracycline hydrochloride $\mathrm{ml}^{-1}$. T. thermophilus HB27 was grown at $65^{\circ} \mathrm{C}$ in defined 162 arginine- and uracil-free (AUF) medium (Piérard \& Wiame, 1964; Degryse et al., 1978) with pyruvate $(20 \mathrm{mM})$ and ammonium sulphate $(10 \mathrm{mM})$ as carbon and nitrogen sources, respectively.

DNA manipulation and transformation. Small-scale plasmid preparations were performed by the cleared lysate method according to Birnboim \& Doly (1979). Large-scale preparations were recovered with Nucleobond AX PC100 (MachereyNagel). Restriction enzymes and T4 ligase were purchased from Boehringer Mannheim and used according to the manufacturer's recommendations. $E$. coli cells were made competent for transformation by $\mathrm{CaCl}_{2}$ treatment (Sambrook et al., 1989).

DNA sequencing strategy. The entire $3 \cdot 2 \mathrm{~kb}$ HindIII fragment of plasmid pTHM1 was cloned in pBluescript $\mathrm{KS}(+)$ in two orientations. Overlapping deletions were generated by use of exonuclease III and S1 nuclease as described by Sambrook $e t$ al. (1989). Preparation of single-stranded DNA template was according to the method of Messing (1983), using R408 as a helper phage. The sequences of both strands were established by the dideoxy chain-termination method (Sanger, 1977). To solve ambiguities in sequence reading due to band compression we substituted the analogue $\mathrm{C}^{7} \mathrm{dGTP}$ for $\mathrm{dGTP}$ in the sequencing mixes (Pharmacia).

Enzyme assays. OAT and $\mathrm{N}$-acetylglutamate synthase were assayed as described by Van de Casteele et al. (1990) at $65^{\circ} \mathrm{C}$. One enzyme unit is defined as the amount of enzyme that converts $1 \mu \mathrm{mol}$ substrate to product per hour. Protein concentrations were determined by the Lowry method.

Computer analysis. Database searches and sequence analyses were performed using the BLAST program (Altschul et al., 1990), the CLUSTAL w program (Thompson et al., 1994) and the GCG package from the University of Wisconsin (Devereux et al., 1984).

Partial purification of OAT. Frozen cells of T. thermophilus from a 15 litre culture $(13.5 \mathrm{~g}$ wet mass) were thawed in $35 \mathrm{ml}$ potassium phosphate buffer $(\mathrm{pH} 7 \cdot 5$; hereafter referred to as phosphate buffer) supplemented with DNase $\left(5 \mu \mathrm{g} \mathrm{ml}^{-1}\right)$ and disrupted by sonication for $15 \mathrm{~min}$ in a Raytheon sonic oscillator $(250 \mathrm{~W}, 10 \mathrm{kHz})$. Intact cells and debris were removed by two consecutive centrifugations $(20000 \mathrm{~g}$, $30 \mathrm{~min}$ ). The supernatant was heated to $95^{\circ} \mathrm{C}$ for $15 \mathrm{~min}$ and cleared of the precipitate by centrifugation $(20000 \mathrm{~g}, 20 \mathrm{~min}$ ). Solid ammonium sulphate was added to the supernatant to $45 \%$ saturation, the solution was stirred for $1 \mathrm{~h}$ and centrifuged at $20000 \mathrm{~g}$ for $30 \mathrm{~min}$. The pellet was suspended in phosphate buffer and extensively dialysed. The dialysed solution $(12.5 \mathrm{ml})$ was loaded on a DEAE-Sepharose XK $16 / 20$ column (Pharmacia), which was washed with $150 \mathrm{ml}$ phosphate buffer and eluted with a linear gradient $(400 \mathrm{ml}$ total volume, $50-500 \mathrm{mM}$ potassium phosphate buffer, $\mathrm{pH} 7 \cdot 5$ ). Active fractions were pooled and concentrated (to $1.2 \mathrm{ml}$ ) by ultrafiltration through an Amicon YM-10 membrane. This concentrated material was applied to a gel filtration Sephadex G-200 SF column (XK 26/40, Pharmacia) and eluted with phosphate buffer. Fractions $(1.4 \mathrm{ml})$ were collected at $5 \mathrm{ml} \mathrm{h}^{-1}$. The gel filtration column was calibrated using the following standards: catalase $\left(M_{\mathrm{r}} 232000\right)$, aldolase $\left(M_{\mathrm{r}} 158000\right)$, albumin $\left(M_{\mathrm{r}} 67000\right)$, ovalbumin $\left(M_{\mathrm{r}} 43000\right)$, chymotrypsinogen A $\left(M_{r} 25000\right)$ and ribonuclease A $\left(M_{r}\right.$ $13700)$.

\section{RESULTS}

\section{Cloning of $T$. thermophilus arginine biosynthetic genes and their expression in $E$. coli}

We cloned the $T$. thermophilus gene responsible for the deacetylation of acetylornithine by heterologous complementation of an E. coli argE mutant (XS1D2), as was done for B. stearothermophilus (Sakanyan et al., 1990), N. gonorrhoeae (Martin \& Mulks, 1992) and C. glutamicum (Sakanyan et al., 1996). HindIII-digested T. thermophilus chromosomal DNA was ligated in a HindIII-digested and dephosphorylated pUC19 vector. The resulting plasmids were transformed into E. coli K$12 \mathrm{XS1D} 2$ and selection for arginine prototrophs was performed on synthetic medium supplemented with succinate and ampicillin. A recombinant plasmid, pTHM1, complementing the E. coli XS1D2 auxotrophy was found to contain a $3.2 \mathrm{~kb}$ insert. This plasmid was tested for its ability to complement other $E$. coli arginine mutants. An argC mutant (XC33) could be complemented, but pTHM1 was unable to restore prototrophy in an $\arg A$ mutant (XA4) or an $\arg A \arg E$ double mutant (XA4argE).

Enzymic assays showed that pTHM1 conferred OAT activity to the $E$. coli XS1D2 mutant [5.6 units (mg protein) ${ }^{-1}$, as compared to 1.3 units (mg protein) ${ }^{-1}$ in $T$. thermophilus extract], thus indicating that $T$. thermophilus uses the cyclic pathway for deacetylation of $\mathrm{N}$ acetylornithine. No $\mathrm{N}$-acetylglutamate synthase activity could be detected in the E. coli XA4 host harbouring pTHM1, corroborating the complementation results. The argJ gene product of $T$. thermophilus thus appears to be monofunctional, as in Pseudomonas, Streptomyces and Corynebacterium (see Introduction).

\section{Sequence analysis}

Analysis of the nucleotide sequence of the pTHM1 $3.2 \mathrm{~kb}$ insert (Fig. 2) revealed the presence of four ORFs, of which the first and last ones were truncated. Comparison of the corresponding amino acid sequences with known arginine metabolic enzymes from different sources allowed us to identify the second ORF as encoding NAGSD $(\arg C)$ and the third one as encoding OAT $(\arg J)($ Table 1$)$. For the corresponding amino acid sequences of the truncated ORFs 1 (468 nt, $156 \mathrm{aa}$ ) and 4 (520 nt, $173 \mathrm{aa}$ ), no homology with any arginine biosynthetic gene and no significant homology with any protein in the SWISSPROT database (BLASTX and BLASTP programs) could be found.

The second ORF, encoding argC, is $1032 \mathrm{nt}$ long. Putative start codons are two GTGs at position 465 and 474 , respectively. In organisms having a high $\mathrm{G}+\mathrm{C}$ content GUG codons are very commonly found (e.g. Micrococcus luteus, $70-75.5 \mathrm{~mol} \% \mathrm{G}+\mathrm{C}$, Ohama et al., 1987; Streptomyces sp., approximately $73 \mathrm{~mol} \%$ $\mathrm{G}+\mathrm{C}$, Zalacain et al., 1986). Only $2 \mathrm{nt} 5^{\prime}$ to the most proximal GTG codon (and $11 \mathrm{nt}$ from the second one) we found a potential ribosome-binding site $\left(5^{\prime}\right.$ GGAGGTG) complementary to the $3^{\prime}$ end sequence of 


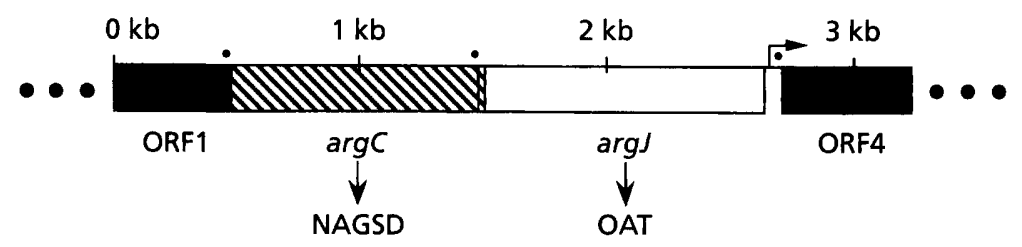

Fig. 2. Organization of the $3.2 \mathrm{~kb}$ HindllI fragment of PTHM1 carrying the argC and argJ genes of $T$. thermophilus. The proposed ribosome-binding sites are indicated by dots and the putative promoter by a bent arrow.

Table 1. Percentage amino acid identity and similarity of $T$. thermophilus $\arg C$ and $\arg J$ gene products and the corresponding gene products in several other organisms (BESTFIT program)

NR, Not relevant; $\mathrm{U}$, sequence unavailable.

\begin{tabular}{|lccccc|}
\hline & \multicolumn{3}{c}{ ArgC } & & \multicolumn{2}{c|}{ ArgJ } \\
\cline { 2 - 3 } \cline { 6 - 7 } & $\%$ similarity & \% identity & & $\%$ similarity & \% identity \\
\hline E. coli & $60 \cdot 6$ & $38 \cdot 7$ & & $\mathrm{NR}$ & $\mathrm{NR}$ \\
N. gonorrhoeae & $\mathrm{U}$ & $\mathrm{U}$ & & $60 \cdot 5$ & $41 \cdot 8$ \\
Synechocystis sp. & $64 \cdot 6$ & $42 \cdot 6$ & & $64 \cdot 3$ & $47 \cdot 3$ \\
Anabaena sp. & $54 \cdot 4$ & $32 \cdot 0$ & & $\mathrm{U}$ & $\mathrm{U}$ \\
B. subtilis & $1 \cdot 1$ & $42 \cdot 2$ & & $62 \cdot 8$ & $43 \cdot 0$ \\
B. stearothermophilus & $62 \cdot 9$ & $45 \cdot 5$ & & $64 \cdot 5$ & $42 \cdot 3$ \\
C. glutamicum & $\mathrm{U}$ & $\mathrm{U}$ & & $57 \cdot 9$ & $38 \cdot 1$ \\
Strep. clavuligerus & $63 \cdot 7$ & $43 \cdot 2$ & & $\mathrm{U}$ & $\mathrm{U}$ \\
M. jannaschii & $66 \cdot 4$ & $42 \cdot 7$ & & $64 \cdot 2$ & $44 \cdot 6$ \\
Sacch. cerevisiae & $57 \cdot 3$ & $32 \cdot 0$ & & $57 \cdot 1$ & $38 \cdot 9$ \\
\hline
\end{tabular}

T. thermophilus $16 \mathrm{~S}$ rRNA (5' GAUCACCUCCUUUCU, Hartmann \& Erdmann, 1989). In E. coli and B. subtilis a $2 \mathrm{nt}$ spacing would result in negligible expression of lacZ (Vellanoweth \& Rabinowitz, 1992) and an $11 \mathrm{nt}$ spacing would reduce expression severely. However, in Thermus a few examples are known of spacings that appear to be as short as 2 or as long as $14 \mathrm{nt}$ (database accession numbers M33159 and D17669). The CLUSTAL w multiple sequence alignment of nine NAGSD enzymes (Fig. 3) favours the GTG at position 474 as possible start codon. Unequivocal elucidation of the start codon will be obtained after purification of the corresponding protein and N-terminal amino acid sequencing.

ORF3, comprising the predicted argJ gene, is $1143 \mathrm{nt}$ long. Nucleotides 1499-1501 encode the ATG start codon; 4 nt upstream a putative Shine-Dalgarno sequence is present $\left(5^{\prime}\right.$ AAGGAGG). The stop codon of $\operatorname{argC}$ overlaps with the translational start of $\arg J$. The organization of these genes would allow translational coupling. A similar arrangement was observed with $T$. thermophilus HB27 $\operatorname{trpB}$ and $\operatorname{trp} A$ genes (Koyama \& Furukawa, 1990) and T. thermophilus HB8 pheS and pheT genes (Kreutzer et al., 1992), and occurs at many other prokaryotic operons whose gene products are required in equimolar amounts. In C. glutamicum (Sakanyan et al., 1996), B. stearothermophilus
(Sakanyan et al., 1993) and B. subtilis (O'Reilly \& Devine, 1994) an intergenic space between the $\operatorname{argC}$ and $\arg J$ genes is present.

In ORF4 an ATG codon is present at position 2714. Four nucleotides upstream a potential RBS is found $\left(5^{\prime}\right.$ AGGTGA). Thirty-three nucleotides further upstream a putative Pribnow box is found ( $5^{\prime}$ TATCCT), preceded by a putative -35 sequence at a distance of $17 \mathrm{bp}\left(5^{\prime}\right.$ TTGACA). These sequence data thus suggest the presence of a promoter in front of ORF4.

The stop codon of the argJ gene overlaps with the putative -35 sequence upstream of ORF4. Downstream of the $\operatorname{argJ}$ gene stop codon no obvious termination signal is present.

Upstream of the $\operatorname{argC}$ gene no obvious promoter sequence can be distinguished. When the $3.2 \mathrm{~kb}$ fragment was cloned in the opposite orientation in pUC19, the resulting plasmid was no longer capable of complementing an E. coli argE mutant; moreover, S1 nuclease mapping of a fragment comprising the $\mathrm{N}$-terminus of the $\arg \mathrm{C}$ gene and an upstream region failed to indicate a transcription start point (data not shown). This indicates that in $E$. coli the $\arg J$ and $\operatorname{argC}$ genes on pTHM1 are not expressed from a promoter located on the $T$. thermophilus fragment but from a vector-encoded one. 


\begin{tabular}{|c|c|}
\hline $\begin{array}{l}\text { T.thermo. } \\
\text { E. coli } \\
\text { Synecho. } \\
\text { Anabaena } \\
\text { B. subt. } \\
\text { B. stearo. } \\
\text { S. Clavi. } \\
\text { M.jann. } \\
\text { S.cerev. }\end{array}$ & $\begin{array}{l}\text { M } \\
\text { LRIIIKLSLEILLILIRIFIPKENPNNKKKIGERMKEVAIIGATGYTGAELIRLLANHER }\end{array}$ \\
\hline $\begin{array}{l}\text { T.thermo. } \\
\text { E.coli } \\
\text { Synecho. } \\
\text { Anabaena } \\
\text { B. subt. } \\
\text { B.stearo. } \\
\text { S.clavu. } \\
\text { M.jann. } \\
\text { S.cerev. }\end{array}$ & 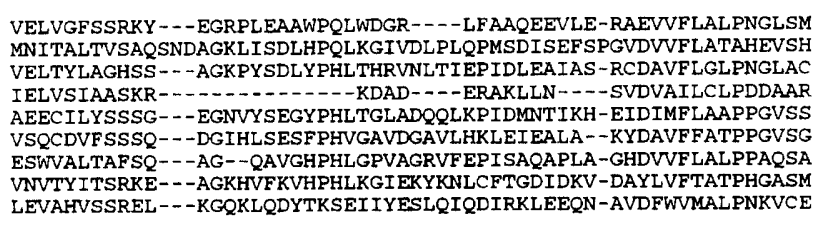 \\
\hline $\begin{array}{l}\text { T.thermo. } \\
\text { E.coli } \\
\text { Synecho. } \\
\text { Anabaena } \\
\text { B. subt. } \\
\text { B. stearo. } \\
\text { S.clavu. } \\
\text { M.jann. } \\
\text { S. cerev. }\end{array}$ & 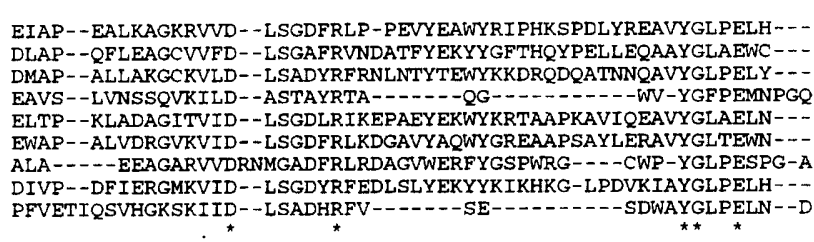 \\
\hline $\begin{array}{l}\text { T. thermo. } \\
\text { E. coli } \\
\text { Synecho. } \\
\text { Anabaena } \\
\text { B. subt. } \\
\text { B. stearo. } \\
\text { S. clavu. } \\
\text { M.jann. } \\
\text { S. cerev. } \\
\\
\text { T. thermo. } \\
\text { E. coli } \\
\text { Synecho. } \\
\text { Anabaena } \\
\text { B. subt. } \\
\text { B.stearo. } \\
\text { S. clavu. } \\
\text { M. jann. } \\
\text { S. cerev. }\end{array}$ & 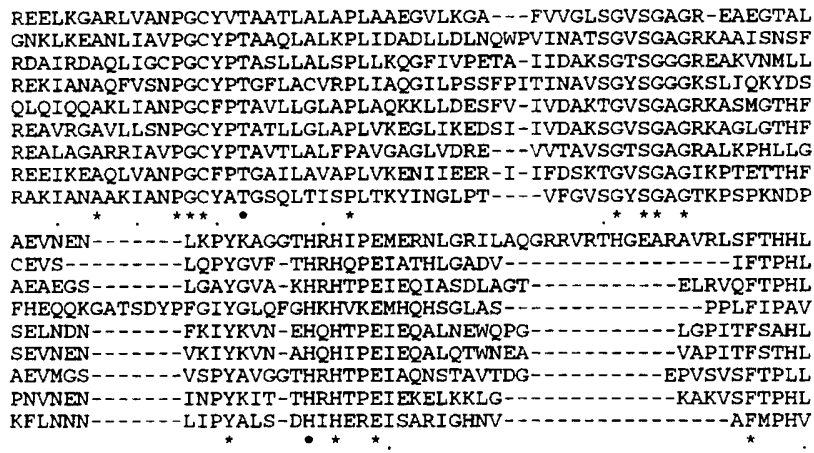 \\
\hline $\begin{array}{l}\text { T.thermo. } \\
\text { E.coli } \\
\text { Synecho. } \\
\text { Anabaena } \\
\text { B.subt. } \\
\text { B.stearo. } \\
\text { S.clavu. } \\
\text { M.jann. } \\
\text { S.cerev. }\end{array}$ & 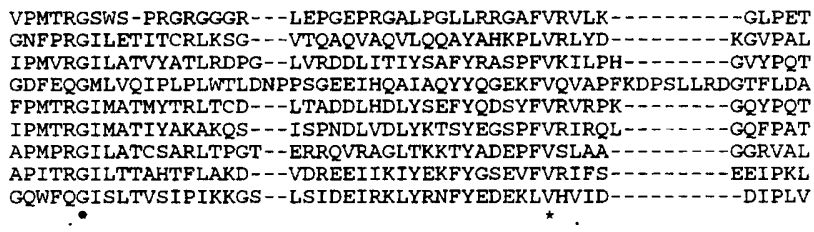 \\
\hline $\begin{array}{l}\text { T. thermo. } \\
\text { E.coli } \\
\text { Synecho. } \\
\text { Anabaena } \\
\text { B. subt. } \\
\text { B.stearo. } \\
\text { S.clavu. } \\
\text { M. jann. } \\
\text { S.cerev. }\end{array}$ & 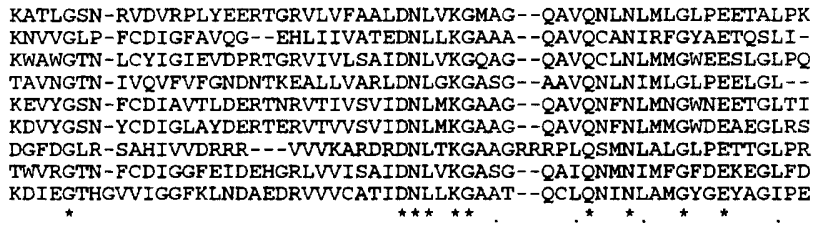 \\
\hline $\begin{array}{l}\text { T. thermo. } \\
\text { E.coli } \\
\text { Synecho. } \\
\text { Anabaena } \\
\text { B. subt. } \\
\text { B. stearo. } \\
\text { S.clavu. } \\
\text { M. jann. } \\
\text { S.cerev. }\end{array}$ & $\begin{array}{l}\text { EGLWP- } \\
\text { LAFYP- } \\
\text { TPIYP- } \\
\text { LPIYP- } \\
\text { TGLAP- } \\
\text { VGLNP- } \\
\text { NKIIGV }\end{array}$ \\
\hline
\end{tabular}

Fig. 3. CLUSTAL $W$ multiple sequence alignment of nine NAGSDs. Similar amino acids are indicated by dots below the alignment and identical amino acids by asterisks. Abbreviations: T.thermo., Thermus thermophilus; E.coli, Escherichia coli (A42377); Synecho., Synechocystis sp. (D90912); Anabaena, Anabaena sp. (S24753); B.subt., Bacillus subtilis (140372); B.stearo., Bacillus stearothermophilus (139765 and Savchenko et al., 1996); S.clavu., Streptomyces clavuligerus (A92987); M.jann., Methanococcus jannaschii (L77117); S.cerev., Saccharomyces cerevisiae (Q01217).

\section{Characteristics of $\operatorname{argC}$}

The $\mathrm{G}+\mathrm{C}$ content of $T$. thermophilus $\arg \mathrm{C}$ is $69.1 \mathrm{~mol} \%$, which is in perfect agreement with that of the species' chromosomal DNA (69 mol\%) (Nagahari et al., 1980). The codon usage is strongly biased towards the use of $\mathrm{G}$ or $\mathrm{C}$ in the first $(71.8 \%)$ and third $(86.7 \%)$ codon positions, the GC frequency in the second codon position $(48.1 \%)$ is comparatively low. The T. thermophilus argC gene product shows significant similarity (similar and identical amino acids) to those of several other micro-organisms (Table 1).

The amino acid composition of $T$. thermophilus NAGSD is listed in Table 2. There is a significant increase in two charged residues (glutamic acid and arginine) in the T. thermophilus enzyme, which could in principle be involved in protein-stabilizing salt bridges. This tendency was also observed in other thermostable enzymes $[B$. stearothermophilus triosephosphate iso- 
Table 2. Percentage amino acid composition of nine NAGSDs

The composition of the sequences was evaluated relative to the residue usage quantile table (Brendel et al., 1992). Low usage in the $5 \%$ quantile is indicated by - , and in the $1 \%$ quantile by - - ; high usage above the $95 \%$ quantile point is indicated by + .

Abbreviations: T.th., Thermus thermophilus; E.co., Escherichia coli; Syne., Synechocystis sp.; Anab., Anabaena sp.; B.su., Bacillus subtilis; B.st., Bacillus stearothermophilus; S.cl., Streptomyces clavuligerus; M.ja., Methanococcus jannaschii; S.ce., Saccharomyces cerevisiae.

\begin{tabular}{|c|c|c|c|c|c|c|c|c|c|}
\hline & $\begin{array}{l}\text { T.th. } \\
\text { (344 aa) }\end{array}$ & $\begin{array}{c}\text { E.co. } \\
(334 \text { aa })\end{array}$ & $\begin{array}{l}\text { Syne. } \\
\text { (351 aa) }\end{array}$ & $\begin{array}{l}\text { Anab. } \\
\text { (322 aa) }\end{array}$ & $\begin{array}{c}\text { B.su. } \\
(345 \text { aa })\end{array}$ & $\begin{array}{c}\text { B.st. } \\
(345 \text { aa) }\end{array}$ & $\begin{array}{c}\text { S.cl. } \\
\text { (340 aa) }\end{array}$ & $\begin{array}{l}\text { M.ja. } \\
(375 \text { aa })\end{array}$ & $\begin{array}{c}\text { S.ce. } \\
(342 \text { aa })\end{array}$ \\
\hline $\mathrm{A}$ & $11 \cdot 3$ & $12 \cdot 0$ & $10 \cdot 3$ & $9 \cdot 3$ & $8 \cdot 4$ & $10 \cdot 7$ & $15 \cdot 3+$ & $5 \cdot 9$ & $7 \cdot 1$ \\
\hline G & $12 \cdot 2+$ & $7 \cdot 8$ & $9 \cdot 4$ & $9 \cdot 3$ & $8 \cdot 1$ & $9 \cdot 3$ & $12 \cdot 1+$ & $7 \cdot 7$ & $8 \cdot 6$ \\
\hline$M$ & 1.5 & $0 \cdot 9$ & $1 \cdot 7$ & $1 \cdot 6$ & $2 \cdot 6$ & $2 \cdot 0$ & $1 \cdot 5$ & $1 \cdot 3$ & $0 \cdot 9$ \\
\hline$S$ & $3 \cdot 5-$ & $4 \cdot 8$ & $4 \cdot 6$ & $6 \cdot 5$ & 4.9 & $6 \cdot 7$ & $5 \cdot 3$ & $3 \cdot 2-$ & 6.5 \\
\hline $\mathrm{C}$ & $0 \cdot 3$ & $2 \cdot 1$ & $2 \cdot 0$ & $0 \cdot 9$ & $1 \cdot 2$ & $0 \cdot 9$ & $0 \cdot 9$ & $0 \cdot 8$ & $1 \cdot 2$ \\
\hline $\mathrm{H}$ & $2 \cdot 3$ & $3 \cdot 6$ & $2 \cdot 3$ & $1 \cdot 9$ & $2 \cdot 9$ & $2 \cdot 6$ & $2 \cdot 4$ & $3 \cdot 5$ & $3 \cdot 1$ \\
\hline $\mathrm{N}$ & $2 \cdot 6$ & $4 \cdot 2$ & $3 \cdot 1$ & $5 \cdot 0$ & $4 \cdot 3$ & $3 \cdot 5$ & $1 \cdot 2-$ & $4 \cdot 5$ & $5 \cdot 9$ \\
\hline $\mathrm{T}$ & $3 \cdot 2-$ & $5 \cdot 1$ & $5 \cdot 1$ & $3 \cdot 7$ & $7 \cdot 0$ & $4 \cdot 3$ & $5 \cdot 9$ & $5 \cdot 9$ & $3 \cdot 7$ \\
\hline $\mathrm{D}$ & $1 \cdot 7-$ & $4 \cdot 5$ & $4 \cdot 8$ & $5 \cdot 6$ & 49 & 4.9 & $3 \cdot 5$ & $4 \cdot 5$ & $5 \cdot 2$ \\
\hline I & $1 \cdot 5-$ & $5 \cdot 4$ & $6 \cdot 3$ & $6 \cdot 2$ & $7 \cdot 0$ & $5 \cdot 8$ & $1 \cdot 5-$ & $11 \cdot 2+$ & $9 \cdot 6+$ \\
\hline$P$ & $7 \cdot 0$ & $5 \cdot 4$ & $6 \cdot 0$ & $6 \cdot 2$ & $5 \cdot 5$ & 4.9 & $7 \cdot 9$ & $4 \cdot 8$ & $4 \cdot 9$ \\
\hline V & $8 \cdot 1$ & $8 \cdot 4$ & $6 \cdot 0$ & $6 \cdot 5$ & $5 \cdot 8$ & $8 \cdot 7$ & $10 \cdot 3+$ & $6 \cdot 4$ & $7 \cdot 4$ \\
\hline$E$ & $9 \cdot 6$ & $4 \cdot 5$ & $4 \cdot 8$ & $5 \cdot 0$ & $6 \cdot 7$ & $6 \cdot 1$ & $4 \cdot 4$ & $8 \cdot 8$ & $5 \cdot 9$ \\
\hline $\mathrm{K}$ & $3 \cdot 8$ & $3 \cdot 6$ & $3 \cdot 4$ & $5 \cdot 0$ & $5 \cdot 2$ & $4 \cdot 3$ & $1 \cdot 5-$ & $9 \cdot 6$ & $6 \cdot 8$ \\
\hline$Q$ & $1 \cdot 5-$ & $5 \cdot 7$ & $4 \cdot 0$ & $6 \cdot 0$ & $4 \cdot 6$ & $3 \cdot 2$ & $2 \cdot 1$ & $0 \cdot 8--$ & $3 \cdot 4$ \\
\hline $\mathrm{W}$ & 1.5 & $0 \cdot 6$ & $1 \cdot 1$ & 0.6 & 0.9 & $1 \cdot 4$ & $1 \cdot 2$ & $0 \cdot 3$ & $0 \cdot 9$ \\
\hline $\mathrm{F}$ & $2 \cdot 3$ & $4 \cdot 2$ & $2 \cdot 0$ & $4 \cdot 7$ & $3 \cdot 2$ & $3 \cdot 2$ & $2 \cdot 6$ & $5 \cdot 1$ & $2 \cdot 8$ \\
\hline $\mathrm{L}$ & $14 \cdot 2+$ & $11 \cdot 4$ & $12 \cdot 8$ & 9.9 & $9 \cdot 6$ & $8 \cdot 7$ & $9 \cdot 7$ & $8 \cdot 5$ & $8 \cdot 6$ \\
\hline $\mathrm{R}$ & $9 \cdot 3+$ & $2 \cdot 4$ & $5 \cdot 1$ & $3 \cdot 1$ & $2 \cdot 9$ & $4 \cdot 1$ & $9 \cdot 1$ & $4 \cdot 0$ & $3 \cdot 4$ \\
\hline $\mathrm{Y}$ & $2 \cdot 6$ & $3 \cdot 6$ & $4 \cdot 8$ & $3 \cdot 1$ & $4 \cdot 3$ & $4 \cdot 6$ & $1 \cdot 8$ & $3 \cdot 2$ & $4 \cdot 0$ \\
\hline $\mathrm{R} / \mathrm{R}+\mathrm{K}^{*}$ & 0.72 & $0 \cdot 4$ & $0 \cdot 38$ & $0 \cdot 48$ & $0 \cdot 36$ & $0 \cdot 86$ & 0.58 & $0 \cdot 33$ & $0 \cdot 29$ \\
\hline
\end{tabular}

$* \mathrm{R} / \mathrm{R}+\mathrm{K}$, number of arginine residues/sum of arginine and lysine residues.

merases, (Rentier-Delrue et al., 1993); T. thermophilus DNA ligase, (Lauer et al., 1991)]. As regards hydrophobic residues, we noted a higher leucine content and a lower isoleucine content. Again, this was observed previously when comparing the $T$. thermophilus DNA ligase to its E. coli homologue (Lauer et al., 1991).

There is only one cysteine residue in T. thermophilus NAGSD and it is probably involved in the reaction mechanism (see Discussion). A lower cysteine content has been reported in several thermophilic enzymes (Koyama \& Furukawa, 1990). The lower content of asparagine and aspartic acid is in agreement with the results of a comparative analysis of triosephosphate isomerase (Rentier-Delrue et al., 1993) but this thermophilic feature, as well as the higher proline content (Watanabe et al., 1991) has to be weighted against a possible bias introduced by the high GC content (see Discussion).

Threonine, serine and glutamine are less abundant than in the other known NAGSDs except that of Methanococcus jannaschii, another extreme thermophile. This proved also to be the case when comparing thermostable DNA ligase to ligases from mesophilic organisms (Lauer et al., 1991) and when comparing triosephosphate isomerase of B. stearothermophilus with that of the psychrotroph Moraxella sp. TA137 (Rentier-Delrue et al., 1993).

Improved protein stability with a higher Arg/Arg + Lys ratio is believed to arise through higher hydrophilicity of arginine residues (Merkler et al., 1981) and through increased hydrogen bonding capability at the guanidinium group of arginine residues (Mrabet $e t$ al., 1992). With the exception of Strep. clavuligerus, the T. thermophilus NAGSD has the highest Arg/Arg + Lys ratio.

The $\arg C$ gene product has a predicted $M_{\mathrm{r}}$ of 37600 and a calculated pI of $9 \cdot 49$.

\section{Characteristics of argJ}

The $\mathrm{G}+\mathrm{C}$ content of the $\arg J$ gene is $70.8 \mathrm{~mol} \%$. A G or $\mathrm{C}$ is found in $69.3 \%$ of the cases in the first codon position, in $50.9 \%$ in the second and in $92.1 \%$ in the third.

The amino acid residues present in eight OATs of different origins are shown in Table 3. Again, the $T$. thermophilus argJ gene product shows trends that have been observed in many thermophilic proteins (see 
Table 3. Percentage amino acid composition of eight OATs

The composition of the sequences was evaluated relative to the residue usage quantile table (Brendel et al., 1992). Low usage in the $5 \%$ quantile is indicated by -, and in the $1 \%$ quantile by - - ; high usage above the $95 \%$ quantile point is indicated by + , and above the $99 \%$ quantile point by ++ . Abbreviations: T.th., Thermus thermophilus; N.go., Neisseria gonnorhoeae; Syne., Synechocystis sp.; B.su., Bacillus subtilis; B.st., Bacillus stearothermophilus; C.gl., Corynebacterium glutamicum; M.ja., Methanococcus jannaschii; S.ce., Saccharomyces cerevisiae.

\begin{tabular}{|c|c|c|c|c|c|c|c|c|}
\hline & $\begin{array}{c}\text { T.th. } \\
\text { (381 aa) }\end{array}$ & $\begin{array}{l}\text { N.go. } \\
\text { (406 aa) }\end{array}$ & $\begin{array}{c}\text { Syne. } \\
(433 \text { aa) }\end{array}$ & $\begin{array}{c}\text { B.su. } \\
(406 \text { aa) }\end{array}$ & $\begin{array}{c}\text { B.st. } \\
(410 \text { aa })\end{array}$ & $\begin{array}{c}\text { C.gl. } \\
\text { (388 aa) }\end{array}$ & $\begin{array}{c}\text { M.ja. } \\
(402 \text { aa) }\end{array}$ & $\begin{array}{c}\text { S.ce. } \\
\text { (441 aa) }\end{array}$ \\
\hline A & $17 \cdot 1++$ & $16 \cdot 3+$ & $13 \cdot 8+$ & $10 \cdot 8$ & $13 \cdot 4+$ & $15 \cdot 7+$ & $8 \cdot 7$ & $7 \cdot 7$ \\
\hline G & $10 \cdot 5$ & $7 \cdot 1$ & $9 \cdot 7$ & $9 \cdot 1$ & $8 \cdot 5$ & $9 \cdot 5$ & $8 \cdot 5$ & $7 \cdot 3$ \\
\hline M & $2 \cdot 4$ & $2 \cdot 5$ & $3 \cdot 0$ & $2 \cdot 2$ & $2 \cdot 9$ & $3 \cdot 1$ & $3 \cdot 2$ & $2 \cdot 7$ \\
\hline$S$ & $2 \cdot 9-$ & $4 \cdot 4$ & $6 \cdot 0$ & $5 \cdot 4$ & $4 \cdot 1$ & $6 \cdot 4$ & $4 \cdot 0$ & $7 \cdot 9$ \\
\hline C & 0.5 & $1 \cdot 5$ & $1 \cdot 4$ & $2 \cdot 0$ & $1 \cdot 7$ & $1 \cdot 5$ & $1 \cdot 5$ & $1 \cdot 6$ \\
\hline $\mathrm{H}$ & $0 \cdot 5-$ & $2 \cdot 0$ & $0 \cdot 5-$ & $2 \cdot 0$ & 1.7 & $0.3-$ & $0.5-$ & $0 \cdot 5-$ \\
\hline $\mathrm{N}$ & $3 \cdot 1$ & $3 \cdot 7$ & 3.7 & $3 \cdot 9$ & $3 \cdot 7$ & $5 \cdot 4$ & $7 \cdot 0$ & $6 \cdot 6$ \\
\hline $\mathrm{T}$ & $5 \cdot 2$ & $8 \cdot 4$ & $8 \cdot 8$ & $7 \cdot 9$ & $8 \cdot 3$ & $8 \cdot 5$ & $6 \cdot 0$ & $8 \cdot 4$ \\
\hline $\mathrm{D}$ & 3.9 & 6.9 & $5 \cdot 5$ & $5 \cdot 4$ & $6 \cdot 3$ & $7 \cdot 7$ & $6 \cdot 5$ & $6 \cdot 3$ \\
\hline I & $3 \cdot 4$ & 6.7 & $5 \cdot 8$ & $7 \cdot 6$ & $5 \cdot 6$ & $4 \cdot 1$ & $7 \cdot 7$ & $6 \cdot 6$ \\
\hline $\mathrm{P}$ & $5 \cdot 0$ & $3 \cdot 7$ & $3 \cdot 5$ & $2 \cdot 7$ & $3 \cdot 4$ & $2 \cdot 8$ & $1.7-$ & $2 \cdot 3$ \\
\hline V & $8 \cdot 1$ & $7 \cdot 1$ & $5 \cdot 3$ & $7 \cdot 4$ & $10 \cdot 2+$ & $9 \cdot 0$ & $10 \cdot 9+$ & $7 \cdot 5$ \\
\hline $\mathrm{E}$ & $8 \cdot 1$ & $4 \cdot 4$ & $3 \cdot 7$ & $8 \cdot 1$ & $5 \cdot 4$ & $4 \cdot 6$ & $9 \cdot 0$ & $4 \cdot 5$ \\
\hline K & $2 \cdot 4$ & $4 \cdot 7$ & $3 \cdot 7$ & 6.9 & $5 \cdot 4$ & $3 \cdot 4$ & $9 \cdot 2$ & $7 \cdot 9$ \\
\hline Q & $1 \cdot 8$ & $4 \cdot 2$ & $6 \cdot 2$ & $3 \cdot 9$ & $4 \cdot 6$ & $3 \cdot 1$ & $0.5--$ & $3 \cdot 4$ \\
\hline W & $1 \cdot 0$ & $0 \cdot 2$ & $1 \cdot 4$ & 0.7 & 0.7 & $0 \cdot 5$ & $0 \cdot 2$ & 0.7 \\
\hline $\mathrm{F}$ & $2 \cdot 4$ & $2 \cdot 7$ & $3 \cdot 7$ & $2 \cdot 2$ & $2 \cdot 0$ & $3 \cdot 1$ & $3 \cdot 7$ & $4 \cdot 1$ \\
\hline $\mathrm{L}$ & $10 \cdot 5$ & $7 \cdot 1$ & $8 \cdot 1$ & $7 \cdot 1$ & $6 \cdot 3$ & $7 \cdot 0$ & $5 \cdot 7$ & $9 \cdot 3$ \\
\hline $\mathrm{R}$ & $8 \cdot 7$ & $4 \cdot 2$ & $4 \cdot 4$ & $2 \cdot 0-$ & $2 \cdot 7$ & $3 \cdot 1$ & $2 \cdot 7$ & $2 \cdot 9$ \\
\hline Y & $2 \cdot 4$ & $2 \cdot 2$ & $1 \cdot 8$ & $2 \cdot 5$ & $2 \cdot 9$ & $1 \cdot 0-$ & $2 \cdot 7$ & $1 \cdot 8$ \\
\hline $\mathrm{R} / \mathrm{R}+\mathrm{K}^{*}$ & 0.79 & 0.47 & 0.48 & 0.33 & $0 \cdot 22$ & 0.54 & $0 \cdot 27$ & $0 \cdot 23$ \\
\hline
\end{tabular}

$* \mathrm{R} / \mathrm{R}+\mathrm{K}$, number of arginine residues/sum of arginine and lysine residues.

above) : a higher presence of arginine, leucine, proline, glycine and alanine; a markedly lower content of serine, cysteine, threonine, aspartic acid, isoleucine, lysine, glutamine (except for M. jannaschii) and asparagine. However, it should be remembered that Lys is only represented by two A-rich codons. As for NAGSD, the Arg/Arg + Lys ratio is highest for the T. thermophilus OAT.

A CLUSTAL $\mathbb{w}$ multiple sequence alignment of the eight known argJ amino acid sequences (Fig. 4) shows that the two monofunctional OAT enzymes (of T. thermophilus and C. glutamicum) are slightly shorter at the Nterminus than the OATs known to be bifunctional ( $B$. stearothermophilus, B. subtilis and N. gonnorboeae).

The calculated $M_{\mathrm{r}}$ of the T. thermophilus OAT is 40300 and the theoretical pI is $5 \cdot 85$.

\section{ORF1 and ORF4 nucleotide and amino acid sequences}

The total $\mathrm{G}+\mathrm{C}$ content of the truncated ORF1 is $66.5 \mathrm{~mol} \%$. The use of $\mathrm{G}$ or $\mathrm{C}$ in the first codon is $75.6 \%$, in the second $39.7 \%$ and in the third $84 \%$. As evidenced by the avoidance of rare codons and the high
GC content in the third position (which is comparable to that of the $\operatorname{argC}$ and $\arg J$ genes), ORF1 is probably part of the coding region for an as yet unidentified protein.

The $\mathrm{G}+\mathrm{C}$ content of the truncated ORF 4 is $60 \cdot 9 \mathrm{~mol} \%$. The use of $\mathrm{G}$ or $\mathrm{C}$ in the first, second and third codon position is $63.6 \%, 43.9 \%$, and $75.1 \%$, respectively. These data deviate from the general rule for Thermus coding regions and the codon usage also deviates from what is commonly seen (Nakamura et al., 1997).

\section{Properties of OAT}

Repression of OAT synthesis by arginine. Addition of $5 \mathrm{mM}$ arginine to the growth medium resulted in a more than twofold repression of OAT activity $[0.5$ units $(\mathrm{mg}$ protein $)^{-1}$ in extract of cells grown in the presence of arginine, as compared to 1.3 units (mg protein) ${ }^{-1}$ in extract of cells grown in minimal medium]. Ornithine had no repressing effect.

Feedback inhibition of OAT. In Fig. 5 the effect on OAT activity of the addition of either ornithine or arginine to the reaction mixture is shown. At saturating levels of substrates arginine had only a weak inhibitory effect 


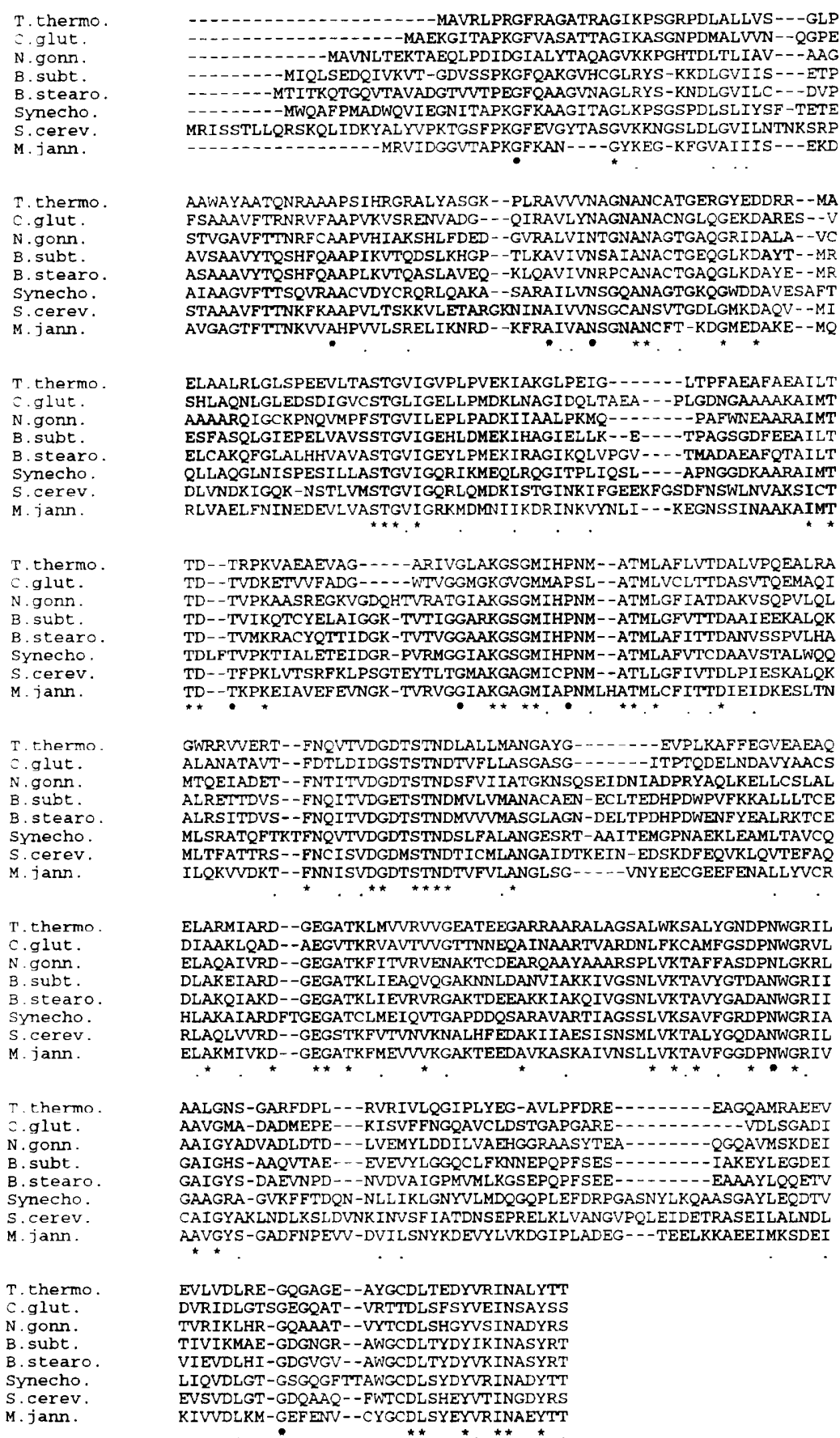

Fig. 4. CLUSTAL $W$ multiple sequence alignment of eight OATs. The upper two enzymes are monofunctional, the $B$. stearothermophilus and Sacch. cerevisiae enzymes are bifunctional (enzymological data) and the $B$. subtilis and $N$. gonorrhoeae enzymes are probably bifunctional (complementation data). For the Synechocystis and Methanococcus enzymes no data are available. Similar amino acids are indicated by dots below the alignment and identical amino acids by asterisks. Abbreviations: T.thermo, Thermus thermophilus; C.glut., Corynebacterium glutamicum (X86157); N.gonn., Neisseria gonorrhoeae (P38434); B.subt., Bacillus subtilis (P36843); B.stearo., Bacillus stearothermophilus (Q07908); Synecho., Synechocystis sp. (D90912); S.cerev., Saccharomyces cerevisiae (M. Crabeel, personal communication); M.jann., Methanococcus jannaschii (L77117). (unlikely to be physiologically significant) with an apparent $K_{\mathrm{i}}$ of $26 \mathrm{mM}$. Under the same conditions, ornithine functions as a much stronger inhibitor, the apparent $K_{\mathrm{i}}$ being $1.4 \mathrm{mM}$.

Partial purification and molecular mass determination of OAT. OAT was purified about 40 -fold from a cellular extract of $T$. thermophilus (see Methods for the purification protocol). The enzyme proved to be very thermostable, retaining $100 \%$ activity after $15 \mathrm{~min}$ at $95^{\circ} \mathrm{C}$. An $M_{\mathrm{r}}$ of $86000 \pm 8000$ was obtained by gel filtration, indicating that the enzyme could be a homodimer.

\section{DISCUSSION}

We have cloned and characterized the T. thermophilus gene $(\arg J)$ encoding the enzyme which deacetylates acetylornithine in the arginine biosynthetic pathway. As in most other micro-organisms (except the Enterobacteriaceae and Sulfolobus, see Introduction), $T$. thermophilus therefore uses the energetically favourable mechanism which recycles the acetyl group of $\mathrm{N}$ acetylornithine onto glutamate. The reaction has already been reported in Thermus ZO5 by Van de Casteele et al. (1990). The synthesis of this OAT was found to be repressible by arginine, which is in keeping 


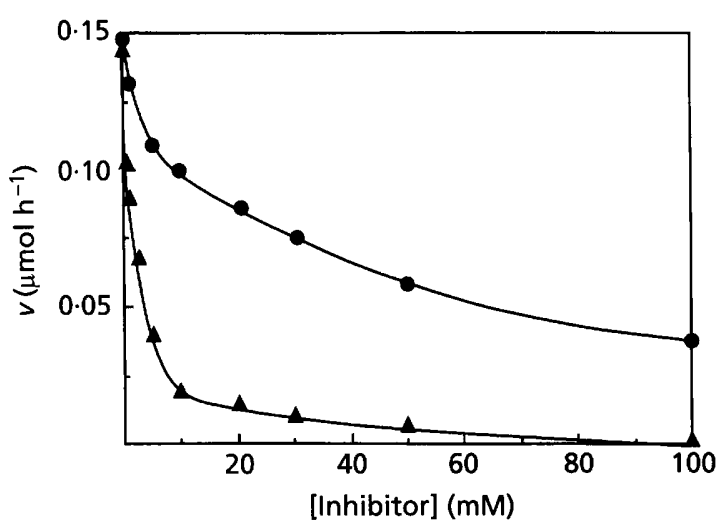

Fig. 5. Inhibition of OAT by ornithine ( $\boldsymbol{A}$ ) and arginine (O). Inhibition was tested by adding inhibitor to the reaction mixture of the enzyme assay described by Van de Casteele et al. (1990).

with its anabolic function. The native enzyme has an $M_{r}$ of 86000 ; from the value derived from the gene sequence (40300) it would appear that the protein is a dimer, as was also postulated by Sakanyan et al. (1993) for B. stearothermophilus. In N. gonorrhoede, the $M_{\mathrm{r}}$ of the argJ gene product was determined to be 46000 by minicell analysis (Martin \& Mulks, 1992). In Sacch. cerevisiae, Liu et al. (1995) showed the enzyme to be a heterodimer of $M_{r} 57000$, with a small subunit of $M_{r}$ 26300 and a large one of $M_{\mathrm{r}} 30700$. This unexpected heterogeneity appears to result from processing of the primary translation product (Liu et al., 1995).

Alignment of eight known OAT sequences (Fig. 4) showed no obvious amino acid pattern that could account for the difference between mono- ( $T$. thermophilus and C. glutamicum) and bi- (B. stearothermophilus, B. subtilis, N. gonnorhoeae and Sacch. cerevisae) functional OATs. The search for a possible pattern is rendered even more problematic by the unexpected lack of any apparent homology between OAT and $\mathrm{N}$ acetylglutamate synthases (Sakanayan et al., 1996). It is notable, however, that the two known sequences of enzymes characterized as monofunctional are somewhat shorter at the N-terminus, which may be correlated with the fact that a fragment lacking a sizeable portion (unsequenced) of $B$. subtilis arg $J$ was reported to complement $\arg E$ but not $\arg A \quad E$. coli mutants (Mountain et al., 1986). It could therefore be interesting to undertake a deletion analysis of bifunctional argJ genes.

Sequence analysis of the total $3 \cdot 2 \mathrm{~kb}$ DNA fragment comprising the $\mathrm{arg} J$ gene demonstrated the presence of an $\operatorname{argC}$ gene immediately upstream, but no putative promoter sequence could be found $5^{\prime}$ to $\operatorname{argC}$. Instead, we found an unidentified ORF. It looks as if these three genetic entities are part of an operon, the more so since the stop codon of $\operatorname{argC}$ overlaps with the start codon of argJ. If ORF1 is functional this would be the first case of an arginine operon including an unrelated gene. By contrast, in the Enterobacteriaceae and in B. stearothermophilus, B. subtilis, Strep. coelicolor and Strep. clavuligerus, $\arg C$ is the first gene of an arginine operon. Downstream of $\arg J$ another unknown ORF is present. It is preceded by a putative promoter sequence, which suggests that it is part of a separate genetic entity. The genetic organization of the arginine biosynthetic genes in T. thermophilus thus appears to be of a new type: ORF1-argC-argJ. Elucidation of up- and downstream sequences is in progress. The possible role of ORF1 is at present entirely conjectural. Clusters of functionally related genes - some of them well characterized operons - containing apparently unrelated ORFs have been reported in other organisms (e.g. see Fani et al., 1995). One hypothesis envisages that such ORFs may code for proteins which contribute to the stabilization of enzymes encoded by the same polycistronic mRNA (Glansdorff, 1997).

Recently Tabata \& Hoshino (1996) mentioned using an $\arg C B$ clone (isolated in their laboratory) in physical mapping of the T. thermophilus HB27 genome. The cognate $\arg C B$ fragment was later described to encode the $\operatorname{argC}$ gene (ORF of $935 \mathrm{bp}, 94.6 \% \mathrm{G}$ or $\mathrm{C}$ in the third codon position) upstream of an $\operatorname{argB}$ gene (ORF of $809 \mathrm{bp}$ ) (Kosuge \& Hoshino, 1996). Both the length of the $\operatorname{argC}$ encoding the ORF and the GC content in the third codon position markedly differ from those described in the present paper (ORF of $1032 \mathrm{bp}, 86.7 \% \mathrm{G}$ or $\mathrm{C}$ in the third codon position). Moreover, the gene sequence $\operatorname{argCB}$ (Tabata \& Hoshino, 1996) differs from $\operatorname{argCJ}$ (found in our laboratory). A possible explanation for this contradictory situation could be that $\operatorname{argC}$ has been duplicated in the genome of $T$. thermophilus HB27 and that the two copies have undergone mutational divergence over a long period of time. We checked this hypothesis by Southern hybridization using a BamHI $\arg C$ gene fragment (isolated from the $3233 \mathrm{bp}$ fragment, see Results) as a probe against BamHI-digested $T$. thermophilus genomic DNA under low stringency conditions (data not shown). However we detected only one hybridizing band on the X-ray film. This leaves the question of two different $\operatorname{argC}$ copies on the $T$. thermophilus HB27 genome open and unresolved. Publication of the $\arg C B$ gene sequence by the Japanese group might help to clarify the situation.

Overall sequence comparisons between the large number of mesophilic and thermophilic proteins which have now been reported do not point to universal 'traffic rules' that would allow firm predictions regarding the molecular basis of thermophily (Daniel et al., 1996). This is due in part to the fact that different molecular strategies may underlie thermophily, but also to the way in which some of the comparisons were made; comparing too distant proteins (even homologous ones) may blur any tendency that could be revealed by comparing the more similar ones within a family of homologous proteins. In the present case, if T. thermophilus OAT (a very stable enzyme) is compared with its homologue from Synechocystis ( $47 \cdot 3 \%$ identity), the trends already 
observed in several other proteins (see Results) assert themselves quite clearly: a lower isoleucine, serine, cysteine, asparagine, threonine and aspartic acid content; and a higher leucine, proline, glutamic acid and arginine content (also a higher Arg/Arg + Lys ratio). The archaeal and presumably thermophilic OAT (from M. jannashii) appears quite different in these respects. The same remarks hold for a comparison between $T$. thermophilus NAGSD and its homologue from $B$. stearothermophilus $(45.5 \%$ identity, its host not growing at the optimal temperature of T. thermophilus), and the trend remains consistent when extending the comparison to other organisms (including a mesophilic Bacillus), except for the archaeon which again appears quite distinct, and Strep. clavuligerus, for which some of the trends vanish. This is not surprising since in organisms with a relatively high $\mathrm{G}+\mathrm{C}$ content, GC-rich codons (e.g. Arg, Pro, Ala, Gly) may be expected to occur with a higher frequency than GC-poor codons (e.g. Asn, Lys, Tyr, Phe, Ile). For example, we find a high proline, glycine and arginine content in Strep. clavuligerus NAGSD the $\mathrm{G}+\mathrm{C}$ content of this bacterium is even higher than in Thermus, $73 \mathrm{~mol} \%$ versus $69 \mathrm{~mol} \%$ ), although this organism is a mesophile. No three-dimensional structure of a NAGSD or OAT is as yet available to put the above considerations to the test and identify which of the observed trends is really significant.

The $\operatorname{argC}$ protein uses NADPH as cofactor. It is therefore interesting to compare the nine sequences now available among themselves [more limited comparisons were done by Ludovice et al. (1992) and Floriano et al. (1992), see below] and to other NADP-specific oxidoreductases. NADP-binding sites have been extensively studied, in particular in glutathione reductase whose three-dimensional structure is known in detail and where coenzyme specificity has been analysed by sitedirected mutagenesis (Scrutton et al., 1990). The site primarily responsible for binding NADPH displays a characteristic $\beta \alpha \beta$ dinucleotide-binding motif (see Wierenga et al., 1985; Hanukoglu \& Gutfinger, 1989), $\mathrm{GXGX}_{2} \mathrm{G} / \mathrm{AX}_{3} \mathrm{AX}_{6} \mathrm{G}$; the $\mathrm{G} / \mathrm{A}$ symbol means that the $A$ can be replaced by a $G$ without any dramatic effect on the kinetic parameters of glutathione reductase for NADPH (Scrutton et al., 1990). When comparing the C-terminal ends of the nine $\operatorname{argC}$ proteins (Fig. 3), a strongly conserved region emerges of structure DNLXKGX $\mathrm{GX}_{3} \mathrm{QX}_{2} \mathrm{NX}_{3} \mathrm{G}$, reminiscent of the above motif by the relative positions of the three $G$ residues. However, the Streptomyces sequence departs from this design by the inclusion of two residues. Two other strongly conserved regions of consensus GXXGXXG and GXSGXG are found in $\operatorname{argC}$ proteins, respectively close to the $\mathrm{N}$-terminus (residues $5-11$ in the T. thermophilus sequence) and towards the middle of the sequence (residues 175-180). As already noted in a previous comparison of five $\operatorname{argC}$ enzymes by Floriano et al. (1992), the latter sequence resembles the phosphate-binding loop of several ATP- or GTP-binding proteins. On the other hand, the N-terminal motif is present between a predicted $\beta$ sheet motif and a putative $\alpha$ helix that could be part of a $\beta \alpha \beta$ fold (data not shown) and the $\mathrm{N}$-terminal position is reminiscent of that of several known FAD-binding sites (Hanukoglu \& Gutfinger, 1989). The presence of more than one, strongly conserved putative motifs for dinucleotide cofactor binding is characteristic of FAD-containing flavoenzymes. Structural studies and mutational analysis are required to conclude which of these sequences are functional in NAGSD but, from the above comparisons, it would not be surprising if it turned out to be a FADcontaining dehydrogenase.

For two other dehydrogenases catalysing the reduction of a phosphorylated carboxyl group to an aldehyde [aspartate semialdehyde dehydrogenase (Haziza et al., 1982) and phosphoglyceraldehyde dehydrogenase (Rossman et al., 1975)], a cysteine is involved in the reaction mechanism. When comparing the three NAGSD sequences known at the time, Parsot et al. (1988) observed a strictly conserved cysteine and tentatively assigned this residue to the active site of the enzyme. In the present alignment of nine NAGSD sequences (Fig. 3), this cysteine residue remains conserved (at position 141 in T. thermophilus) as well as several other residues in its vicinity: $\mathrm{AX}_{5} \mathrm{PGCX}_{2} \mathrm{TX}_{7} \mathrm{P}$. Besides, in Thermus, this is the only cysteine found in the protein. This result therefore strongly supports the suggestion of Parsot et al. (1988) of a role of this cysteine in the reaction mechanism.

In the absence of structural information, the strongly conserved P-loop motif found from residue 175 to residue 180 (see previous section) appears as a possible candidate for recognition of the phosphoryl group of $\mathrm{N}$ acetylglutamylphosphate.

In the cyclic pathway of ornithine synthesis, OAT may play the role of key enzymic step determining the flux of arginine precursors instead of acetylglutamate kinase, as shown for the first time in Thermus ZO5 where arginine was found indeed to inhibit the activity of that enzyme (Van de Casteele et al., 1990). In T. thermophilus we found arginine to be only a weak inhibitor of OAT; ornithine however inhibits OAT with an apparent inhibition constant of $1.4 \mathrm{mM}$. This is still a relatively high value but it must be taken into account that it was determined at saturating concentrations of substrates and in crude extracts. Since Thermus ZO5, a closely related species, makes an inducible arginase converting arginine into ornithine and urea (C. Legrain, unpublished), $T$. thermophilus is likely to synthesize this enzyme as well; ornithine might therefore be able to curtail the flow of arginine precursors if its intracellular concentration can reach a high enough value. A similar situation was reported in B. stearothermophilus, where the inhibition of OAT by ornithine is however stronger (Sakanyan et al., 1993).

Cloning of up- and downstream sequences relative to the ORF1-argC-argJ-ORF4 comprising 3233 bp frag- 
ment is in progress. It is expected to reveal more information on the organization of arginine biosynthetic genes in T. thermophilus and on their regulation.

\section{ACKNOWLEDGEMENTS}

We thank M. Demarez for technical assistance. This work was supported by grants from the Belgian Fund for Joint Basic Research (FRFC-FKFO), by the European Community Programme for Biotechnology, by the Vlaams Actieprogramma Biotechnologie and by the Research Council of the Vrije Universiteit Brussel.

\section{REFERENCES}

Altschul, S. F., Gish, W., Miller, W., Myers, E. W. \& Lipman, D. J. (1990). Basic local alignment search tool. J Mol Biol 251, 403-410.

Birnboim, H. C. \& Doly, J. (1979). A rapid alkaline extraction procedure for screening recombinant DNA. Nucleic Acids Res 7, 1513-1523.

Brendel, V., Bucher, P., Nourbakhsh, I. R., Blaisdell, B. E. \& Karlin, S. (1992). Methods and algorithms for statistical analysis of protein sequences. Proc Natl Acad Sci USA 89, 2002-2006.

Crabeel, M., Abadjeva, A., Hilven, P., Desimpelaere, J. \& Soetens, O. (1997). Characterization of the Saccharomyces cerevisiae ARG7 encoding ornithine acetyltransferase, an enzyme also endowed with acetylglutamate synthase activity. Eur J Biochem (in press).

Cunin, R., Glansdorff, N., Piérard, A. \& Stalon, V. (1986). Biosynthesis and metabolism of arginine in bacteria. Microbiol Rev 50, 314-352.

Daniel, R. M., Dines, M. \& Petach, H. H. (1996). The denaturation and degradation of stable enzymes at high temperatures. Biochem J 317, 1-11.

Davis, R. H. (1986). Compartmental and regulatory mechanisms in the arginine pathways of Neurospora crassa and Saccharomyces cerevisae. Microbiol Rev 50, 280-313.

Degryse, E., Glansdorff, N. \& Piérard, A. (1978). A comparative analysis of extreme thermophilic bacteria belonging to the genus Thermus. Arch Microbiol 117, 189-196.

Devereux, J., Haeberli, P. \& Smithies, O. (1984). A comprehensive set of sequence analysis programs for the VAX. Nucleic Acids Res 12, 387-395.

Elseviers, D. R., Cunin, R., Glansdorff, N., Baumberg, S. \& Ashcroft, E. (1972). Control regions within the $\operatorname{argECBH}$ gene cluster of Esherichia coli K12. Mol Gen Genet 117, 349-366.

Falmagne, P., Vanderwinkel, E. \& Wiame, J. M. (1965). Mise en evidence de deux malate synthetases chez Escherichia coli. Biochim Biophys Acta 99, 246-258.

Fani, R., Lio, P. \& Lazeano, A. (1995). Molecular evolution of the histidine biosynthetic pathway. J Mol Evol 41, 760-774.

Floriano, B., Herrero, A. \& Flores, E. (1992). Isolation of arginine auxotrophs, cloning by mutant complementation, and sequence analysis of the $\arg C$ gene from the cyanobacterium Anabaena species PCC 7120. Mol Microbiol 6, 2085-2094.

Glansdorff, N. (1965). Topography of cp-transducible arginine mutations in E. coli K12. Genetics 51, 167-179.

Glansdorff, N. (1996). Biosynthesis of arginine and polyamines. In Escherichia coli and Salmonella: Cellular and Molecular Biology, pp. 408-433. Edited by F. Neidhardt and others. Washington, DC: American Society for Microbiology.
Glansdorff, N. (1997). On the origin of operons and their possible role in evolution towards thermophily. $J \mathrm{Mol}$ Evol (in press).

Haas, D. \& Holloway, B. W. (1977). The genetic organization of arginine biosynthesis in Pseudomonas aeruginosa. Mol Gen Genet 154, 7-22.

Hanukoglu, I. \& Gutfinger, T. (1989). cDNA sequence of adrenodoxin reductase. Identification of NADP-binding sites in oxidoreductases. Eur J Biochem 180, 479-484.

Hartmann, R. K. \& Erdmann, V. A. (1989). Thermus thermophilus HB8 16S rRNA is transcribed from an isolated transcription unit. J Bacteriol 171, 2933-2941.

Harwood, C. R. \& Baumberg, S. (1977). Arginine hydroxamateresistant mutants of Bacillus subtilis with altered control of arginine metabolism. J Gen Microbiol 100, 177-188.

Haziza, C., Stragier, P. \& Patte, J. C. (1982). Nucleotide sequence of the asd gene of Escherichia coli: absence of a typical attenuation signal. EMBO J 1, 379-384.

Hindle, Z., Callis, R., Dowden, S., Rudd, B. A. M. \& Baumberg, S. (1994). Cloning and expression in Escherichia coli of a Streptomyces coelicolor A3(2) argCJB gene cluster. Microbiology 140, 311-320.

Kosuge, T. \& Hoshino, T. (1996). Analysis of amino acid biosynthetic genes and enzymes of Thermus thermophilus. In Thermophiles' '96, Conference Abstracts, p. 146. Athens, Georgia : University of Georgia.

Koyama, Y. \& Furukawa, K. (1990). Cloning and sequence analysis of tryptophane synthetase genes of an extreme thermophile, Thermus thermophilus HB27: plasmid transfer from replicaplated Escherichia coli recombinant colonies to competent $T$. thermophilus cells. J Bacteriol 172, 3490-3495.

Kreutzer, R., Kruft, V., Bobkova, E., Lavrik, O. I. \& Sprinzl, M. (1992). Structure of the phenylalanyl-tRNA synthetase genes from Thermus thermophilus HB8 and their expression in Escherichia coli. Nucleic Acids Res 20, 4173-4178.

Lauer, G., Rudd, E. A., McKay, D. L., Ally, A., Ally, D. \& Backman, K. C. (1991). Cloning, nucleotide sequence, and engineered expression of Thermus thermophilus DNA ligase, a homolog of E. coli DNA ligase. J Bacteriol 173, 5047-5053.

Liang, Z. (1997). Physiology and molecular biology of enzymatic carbamoylation in marine psychrophilic bacteria. PhD thesis, Vrije Universiteit Brussel.

Liang, Z., Demarez, M., Legrain, C., Baetens, M., Glansdorff, N., Ruger, H. J. \& Tan, T. L. (1996). Ornithine carbamoyltransferase from obligate psychrophilic bacteria. Arch Physiol Biochem 104, B15.

Liu, Y., Van Heeswijck, R., Hoj, P. \& Hoogenraad, N. (1995). Purification and characterization of OAT from Saccharomyces cerevisae. Eur J Biochem 228, 291-296.

Ludovice, M., Martin, J. F., Carrachas, P. \& Liras, P. (1992). Characterization of the Streptomyces clavuligerus argC gene encoding $\mathrm{N}$-acetylglutamyl-phosphate reductase: expression in Streptomyces lividans and effect on clavulanic acid production. $J$ Bacteriol 174, 4606-4613.

Martin, P. R. \& Mulks, M. H. (1992). Molecular characterization of the argJ mutation in Neisseria gonorrboeae strains with requirements for arginine, hypoxanthine, and uracil. Infect Immun 60, 970-975.

Matsumoto, H., Hosogaya, S., Suzuki, K. \& Tazaki, T. (1975). Arginine gene cluster of Serratia marcescens. Jpn J Microbiol 19, $35-44$.

Merkler, D. J., Farrington, G. K. \& Wedler, F. C. (1981). Protein thermostability. Correlations between calculated macroscopic 
parameters and growth temperature for closely related thermophilic and mesophilic Bacilli. Int J Pept Protein Res 18, 430-442.

Messing, J. (1983). New M13 vectors for cloning. Methods Enzymol 101, 20-78.

Messing, J. \& Vieira, J. (1982). A new pair of M13 vectors for selecting either DNA strand of double digest restriction fragments. Gene 19, 269-276.

Mountain, A., Mann, N. H., Munton, R. N. \& Baumberg, S. (1984). Cloning of a Bacillus subtilis restriction fragment complementing auxotrophic mutants of eight $E$. coli genes of arginine biosynthesis. Mol Gen Genet 197, 82-89.

Mountain, A., McChesney, J., Smith, M. C. M. \& Baumberg, S. (1986). Gene sequence encoding early enzymes of arginine synthesis within a cluster in Bacillus subtilis, as revealed by cloning in Escherichia coli. J Bacteriol 165, 1026-1028.

Mrabet, N. T., Van de Broeck, A., Van den Brande, I. \& 13 other authors (1992). Arginine residues as stabilizing elements in proteins. Biochemistry 31, 2239-2253.

Nagahari, K., Koshikawa, T. \& Sakaguchi, K. (1980). Cloning and expression of the leucine gene from Thermus thermophilus in Escherichia coli. Gene 10, 137-145.

Nakamura, Y., Gojobori, T. \& Ikemura, T. (1997). Codon usage tabulated from the international DNA sequence databases. Nucleic Acids Res 25, 244-245.

Ohama, T. , Yamao, F., Muto, A. \& Osowa, S. (1987). Organization and codon usage of the streptomycin operon in Micrococcus luteus, a bacterium with a high genomic $\mathrm{G}+\mathrm{C}$ content. J Bacteriol $169,477()-4777$.

O'Reilly, M. \& Devine, K. M. (1994). Sequence and analysis of the citrulline biosynthetic operon argC-F from Bacillus subtilis. Microbiology 140, 1023-1025.

Oshima, T. \& Imahori, K. (1974). Description of Thermus thermophilus (Yoshida and Oshima), comb. nov., a nonsporulating thermophilic bacterium from a Japanese spa. Int J Syst Bacteriol 24, 102-112.

Parsot, C., Boyen, A., Cohen, G. N. \& Glansdorff, N. (1988). Nucleotide sequence of Escherichia coli $\arg B$ and $\arg C$ genes: comparison of $N$-acetylglutamate- $\gamma$-semialdehyde dehydrogenase with homologous and analogous enzymes. Gene 68, 275-283.

Picard, F. J. \& Dillon, J. R. (1989). Cloning and organization of seven arginine biosynthetic genes from Neisseria gonorrhoeae. $J$ Bacteriol 171, 1644-1651.

Piérard, A. \& Wiame, J. M. (1964). Regulation and mutation affecting a glutamine dependent formation of carbamoylphosphate in Escherichia coli. Biochem Biophys Res Commun 15, 76-81.

Pouwels, P., Cunin, R. \& Glansdorff, N. (1974). Divergent transcription in the $\operatorname{argECBH}$ cluster of genes in Escherichia coli K-12. J Mol Biol 83, 421-424.

Prozesky, O. W. (1968). Transductional analysis of arginineless mutants in Proteus mirabilis. J Gen Microbiol 54, 127-143.

Rentier-Delrue, F., Mande, S. C., Moyens, S., Terpstra, P., Mainfroid, V., Goraj, K., Lion, M., Hol, W. G. J. \& Martial, J. A. (1993). Cloning and overexpression of the triose phosphate isomerase genes from psychrophilic and thermophilic bacteria. Structural comparison of the predicted protein sequences. $J \mathrm{Mol}$ Biol 229, 85-93.

Rossman, M. G., Liljas, A., Brăndén, C. I. \& Banaszak, L. J. (1975). Evolutionary and structural relationships among dehydrogenases. In The Enzymes, vol. 11, pp. 61-102. Edited by P. Boyer. New York: Academic Press
Sakanyan, V. A., Hovsepyan, A. S., Mett, I. L., Kochikyan, A. V. \& Petrosyan, P. K. (1990). Molecular cloning and structural-functional analysis of the arginine biosynthesis genes of the thermophilic bacterium Bacillus stearothermophilus. Genetika 26, 1915-1925.

Sakanyan, V., Kochikyan, A., Mett, I., Legrain, C., Charlier, D., Piérard, A. \& Glansdorff, N. (1992). A re-examination of the pathway for ornithine biosynthesis in a thermophilic and two mesophilic Bacillus species. J Gen Microbiol 138, 125-130.

Sakanyan, V., Charlier, D., Legrain, C., Kochikyan, A., Mett, I., Piérard, A. \& Glansdorff, N. (1993). Primary structure, partial purification and regulation of key enzymes of the acetyl cycle of arginine biosynthesis in Bacillus stearothermophilus: dual function of ornithine acetyltransferase. J Gen Microbiol 139, 393-402.

Sakanyan, V., Petrosyan, P., Lecocq, M., Boyen, A., Legrain, C., Demarez, M., Hallet, J.-N. \& Glansdorff, N. (1996). Genes and enzymes of the acetyl cycle of arginine biosynthesis in Corynebacterium glutamicum: enzyme evolution in the early steps of the arginine pathway Microbiology 142, 99-108.

Sambrook, J., Fritsch, E. F., Maniatis, T. (1989). Molecular Cloning: a Laboratory Manual, 2nd edn. Cold Spring Harbor, NY: Cold Spring Harbor Laboratory.

Sanderson, K. E. (1970). Current linkage map of Salmonella typhimurium. Bacteriol Rev 34, 176-193.

Sanger, F., Nicklen, S. \& Coulson, A. R. (1977). DNA sequencing with chain-terminating inhibitors. Proc Natl Acad Sci USA 74, 5463-5467.

Savchenko, A., Charlier, D., Dion, M., Weigel, P., Hallet, J.-N., Holtman, C., Baumberg, S., Glansdorff, N. \& Sakanyan, V. (1996). The arginine operon of Bacillus stearothermophilus: characterization of the control region and its interaction with the heterologous Bacillus subtilis arginine repressor. Mol Gen Genet $252,69-78$.

Scrutton, N. S., Berry, A. \& Perham, R. N. (1990). Redesign of the coenzyme specificity of a dehydrogenase by protein engineering. Nature 343, 38-43.

Short, J. M., Fernandez, J. M., Sorge, J. A. \& Huse, W. D. (1988). $\lambda$ ZAP : a bacteriophage $\lambda$ expression vector with in vivo excision properties. Nucleic Acids Res 16, 7583-7600.

Tabata, K. \& Hoshino, T. (1996). Mapping of 61 genes on the refined physical map of the chromosome of Thermus thermophilus HB27 and comparison of genome organization with that of T. thermophilus HB8. Microbiology 142, 401-410.

Thompson, J. D., Higgins, D. G. \& Gibson, T. J. (1994). CLUSTAL w : improving the sensitivity of progressive multiple sequence alignment through sequence weighting, position specific gap penalties and weight matrix choice. Nucleic Acids Res 22, 4673-4680.

Van de Casteele, M. (1994). The metabolic and genetic control of carbamoylation in extreme thermophilic eubacteria. $\mathrm{PhD}$ thesis, Vrije Universiteit Brussel.

Van de Casteele, M., Demarez, M., Legrain, C., Glansdorff, N. \& Piérard, A. (1990). Pathways of arginine biosynthesis in extreme thermophilic archaeo- and eubacteria. J Gen Microbiol 136, 1177-1183.

Van de Casteele, M., Desmarez, L., Legrain, C., Chen, P. G., Van Lierde, K., Piérard, A. \& Glansdorff, N. (1994). Genes encoding aspartate carbamoytransferase of Thermus aquaticus ZOS and Thermotog a maritima MSB8: modes of expression in Escherichia coli and properties of their products. Biocatalysis 112, 165-179.

Van de Casteele, M., Legrain, C., Desmarez, L., Chen, P. G., Piérard, A. \& Glansdorff, N. (1997a). Molecular physiology of 
carbamoylation under extreme conditions: what can we learn from extreme thermophilic organisms? Comp Biochem Physiol (in press).

Van de Casteele, M., Chen, P., Roovers, M., Legrain, C. \& Glansdorff, N. (1997b). Structure and expression of a pyrimidine gene cluster from the extreme thermophile Thermus ZO5. J Bacteriol 11, 3470-3481.

Vellanoweth, R. L. \& Rabinowitz, J. C. (1992). The influence of ribosome-binding-site elements on translational efficiency in Bacillus subtilis and Escherichia coli in vivo. Mol Microbiol 6, 1105-1114.

Vyas, S. \& Maas, W. (1963). Feed-back inhibition of acetylglutamate synthase by arginine in Escherichia coli. Arch Biochem Biophys 100, 542-546.

Watanabe, K., Chishiro, K., Kitamura, K. \& Suzuki, Y. (1991). Proline residues responsible for thermostability occur with high frequency in the loop regions of an extremely thermostable oligo- 1,6-glucosidase from Bacillus thermoglucosidasius KP1006. J Biol Chem 266, 24287-24294.

Wierenga, R. K., Terpstra, P. \& Hol, W. G. J. (1985). Prediction of the occurrence of the ADP-binding $\beta \alpha \beta$-fold in proteins, using an amino acid sequence fingerprint. J Mol Biol 187, 101-107.

Williams, R. A. D. (1992). The genus Thermus. In Thermophilic Bacteria, pp. 51-62. Edited by J. K. Kristjansson. Boca Raton, FL: CRC Press.

Woese, C. R. (1987). Bacterial evolution. Microbiol Rev 51, 221-271.

Zalacain, M., Gonzalez, A., Guerrero, M. C., Mattaliano, R. J., Malpartida, F. \& Jimenez, A. (1986). Nucleotide sequence of the hygromycin B phosphotransferase gene from Streptomyces hygroscopicus. Nucleic Acids Res 14, 1565-1581.

Received 23 June 1997; revised 22 September 1997; accepted 26 September 1997. 